\title{
Ways to open innovation: Main agents and sources in the Portuguese case
}

\begin{abstract}
Facing increasing open innovation trends, Portuguese enterprises are considering the related processes and impacts. Thus, this work aims to identify the sectors whose enterprises most engage in open innovation (such as cooperation on this issue) and which sources/agents are most used. This is analyzed by sector and type of innovation as an interesting way of differentiation for better open innovation strategy delineation. Using the data from the Community Innovation Survey (CIS-2012), it first appraises the nature of the innovation process, either cooperative or firm-based, as the starting level of analysis. Then, it differentiates the results by sector illustrating which cooperation sources/agents are most used (scope) and relative intensity of use (scale).

This is important to assess levels of openness and related factors. Results show that main innovating sectors in Portugal are of three types: research-based, knowledge-based and service-based. They reveal an increasing focus on knowledge and services, trends that have been leading to more active openness towards innovation. For instance, health and construction are increasing their openness for innovating and internationalizing processes. However, Portuguese innovation is still more firm-based (in-house) than cooperation-based, especially concerning new products' launching. This work and future analyses around it can contribute to encourage the open innovation strategy in more sectors of the economy as an easy and effective way to cope with rapid trends and changes.
\end{abstract}

\section{Introduction}

In today's knowledge-intensive economies, enterprises have to cope with strong and dynamic challenges. Facing instability and uncertainty they ought to provide a constant stream of innovations to clients. Then, external expert knowledge and sources can be very effective in dealing with these issues and achieve business success. Firms are able to create a steady demand for their products/services if they constantly readjust their strategies. Researchers suggest that firms can reshape the market through their innovations, for which can contribute some external sources/agents. Economic performance is enhanced by enterprises' ability to offer solutions to changing needs and structures. More enterprises acknowledge that change is not only important, but also compulsory due to the fact that they constantly face a fast changing market.

The process of developing an innovation may imply three types of approach: make; buy or cooperate with other agents to acquire specific competences or knowledge. The last occurs when the firms' internal knowledge or skill-base is not sufficient or effective and is conveniently complemented with external sources. Several studies on open innovation (OI) support that firm's boundaries require porosity in order to absorb knowledge and capabilities from the external environment. This can provide an extensive variety of ideas, opportunities, sharing of costs/risks and resources. Clients constantly demand new services, according to their exposure to external information and trends (even through social networks, virtual worlds, etc.). Therefore firms need to correspond to their expectations and satisfy their needs. A work about this issue, based on a sample of 70 firms in Algarve (Belo et al., 2016), shows that firms are already using social networks for customer knowledge acquisition and not only for advertising 
purpose. And this is a new form of OI throughout social networked connections; for example knowing in which co-investment clusters other investors are embedded and how it affects their decisions where to invest has great importance (Hayat, 2014).

Firms' cooperation, among them or with clients or other stakeholders, and its potential for innovation is not new. The literature confirms that firms that do not co-operate, and do not formally or informally exchange knowledge, limit their long-term knowledgebase and, ultimately, reduce their ability to enter into exchange relationships (Hanna \& Walsh, 2008; Pittaway et al., 2004). More specifically, regarding product and process innovation, positive associations were found in cooperation with customers, suppliers, the public sector and universities (Freel \& Harrison, 2006). This is very important for Portugal due to its moderate innovation index (European Innovation Scoreboard- EIS, 2017) related, among other factors, with low incomes in the country, missing early collective entrepreneurial culture, difficulties obtaining finance and risk adversity (Sarkar, 2014).

This work aims at identifying the sectors of the Portuguese economy that most engage in cooperation to develop innovation and which sources/agents they mostly use, by sector and type of innovation (with incidence in product and process innovations). This kind of approach is relevant as it suggests an analysis of patterns in terms of scope (variety) and scale (intensity) of use, for better OI strategy delineation from the assessment of openness levels and related factors. To attain these objectives, it is structured as follows: next section makes a literature review on the trends of OI and main related sources/agents; third section describes the research framework (proposition, instrument, sampling, frequencies) for appraising the nature of the innovation process (cooperation or firm-based) by type of innovation (product vs. process); fourth section differentiates these results by sector outlining which cooperation sources/agents are most used (scope) and relative intensity (scale); then last section concludes and refers future related work and practical implications.

\section{Literature review}

Innovation is a theme of interest for researchers in different disciplines such as strategy, information technology, marketing, entrepreneurship or even engineering and product design. It is important to mention that it can only be considered an innovation when the enterprise develops an invention that is introduced in the market and is commercialized bringing economic return to the firm (Kuznets, 1962). Innovation can be achieved in a variety of elements depending on the enterprise's resources, capabilities, requirements and strategies. The most common types of innovation refer to products, materials, services or organizational structures (Ettlie \& Reza, 1992). Other authors (Pavitt et al., 1987; Lundvall, 1988; Cornish, 1997) have focused on different sources and types of innovation. For instance, Propris (2002) concentrated her investigation on the impact of inter-firm cooperation over innovation on four different dimensions of innovation: product, process, incremental and radical innovation.

Today it is more difficult for enterprises to maintain a competitive advantage only through internal R\&D (research and development), due to technology or market discontinuities caused by several changes. Given the complexity of this environment, enterprises need to complement their internal sources and capabilities with ideas from outside, interacting with a wide range of actors. This contribution to internal R\&D can 
give enterprises access to complementary assets, needed to turn an idea into a successful product/service. Thus, many firms seek external partners and knowledge in order to compete in this dynamic and fast changing context.

\subsection{Open innovation trends}

The OI paradigm has been generally described through two modes (Chesbrough et al., 2006): 1) outbound mode (inside->out process) referring to external exploitation of internal knowledge (e.g., selling patents, direct licensing, etc.; and 2) inbound mode (outside->in process) referring to internal use of external knowledge (resorting to partners, customers, universities, research institutes, etc.). According to Chesbrough and other authors, the initial usage of external knowledge changed from a supplemental role to internal knowledge towards an acknowledged equal-level-of-importance of external and internal knowledge (OI model). This model evolved to the condition in which the organizations actively cooperate to co-develop product or process innovations (Piller \& West, 2014). The most committed approach to the OI paradigm implies active collaborating with other organizations rather than merely importing knowledge, competences and innovations (Cricelli et al., 2016).

It is interesting to mention that some authors such as Greco et al. (2016) acknowledged that OI is not linearly (or proportionally) related with innovation performance. Overcollaboration phenomena might reduce the OI marginal returns when a firm resorts to additional external innovation partners.

According to the European firms adopting OI, the share that developed inbound OI mode (outside->in) is higher than the portion adopting the outbound mode (Michelino et al., 2014). This work shows how inbound OI has higher impact in improving firms' financial performance. Cricelli et al. (2016) also observed that the share of firms adopting the inbound OI mode is higher. That is why we analyze this issue in Portugal due to its moderate innovation index (according to the EIS 2017), to its low incomes and current crisis. Also why we used the typology of sources/agents next referred.

\subsection{Innovation and its assets}

Fast changing factors such as technology, customers or competitors force enterprises to renew their strategy in order to survive, reshaping their activities, in particular innovation development. The process of developing an innovation normally implies two types of strategy: generate knowledge in-house (make) or purchase it (buy) (Veugelers \& Cassiman, 1999). Nevertheless, in recent times theorists have detected a third strategy for acquiring knowledge: cooperation with other agents (Navarro, 2002). Strategy specialists have demonstrated that agents from outside the enterprise constitute a significant source in modern competitive context, especially in developing new products and processes (Peteraf, 1993). The enterprise's intention to cooperate with other agents for innovation is impelled by the fact that it is an efficient way to improve the chances of differential products/services (Becker \& Dietz, 2004; Abramovsky et al., 2005, Sampson, 2007). Besides, enterprises that are highly internally focused, not opening themselves to external networks and relationships, may miss a lot of interesting combinations (Chesbrough, 2003; Laursen \& Salter, 2006).

However, literature states that enterprises' performance depends on their ability to locate, absorb and exploit those sources in a productive way (Cohen \& Levinthal, 
1990). Several other factors support the firm's decision to cooperate: e.g., share expenses and uncertainty, exploit synergies, recognize economies of scale/scope, as well as benefit from government support (Veugelers \& Cassiman, 1999; Becker \& Dietz, 2004; Enkel et al., 2009). The innovation process may involve external sources from different origins ranging from customers, suppliers, universities to competitors, among other agents (Von Hippel, 2005; Powell et al., 1996).

\section{Customers}

Customers can be the cooperation agent with greatest impact on the intensity of innovation activities, somewhat because it is a vertical or non-competitive cooperation. Their involvement in the manufacturing and service sectors is a good example of their contribution in new product development (Sánchez-González \& Herrera, 2014). The success of product innovations in public sector institutions is also highly related to cooperation with customers (Freel \& Harrison, 2006). This external partner is an important source of knowledge because its inputs help firms to identify new ideas about products and solutions, understand customers' attitudes, and identify new market trends in advance. For example, high-tech industries benefit from customers contribution particularly to learn about technological trends and develop superior products (Brettel \& Cleven, 2011). Some firms invite customers to participate in the innovation process, most frequently in the design of the next new product (e.g., the online Lego DesignbyMe tool). Regarding complex technologies and/or products, this external source provides particularly valuable information (Von Hippel, 2005; Tether, 2002). The similar principle applies when the product presents a high level of novelty (Amara \& Landry, 2005). This can be explained by the fact that the user's experience can be of great help, either to reshape or improve the existing design or give ideas for new models and applications. Apart from improving the product design, collaboration with customers provide a more controlled development of the innovation process taking less time and lower costs (Jeppesen, 2002).

\section{Suppliers}

The relationship with suppliers is also considered as a vertical or non-competitive cooperation. It is a fact that enterprises have increased their relationships with their suppliers from the 1980s, mainly because of Japanese car and electronics successful relationship in developing innovations (Bidault et al., 1998). According to Håkansson and Eriksson (1993), suppliers are base factors of business. These players can be a source of innovative ideas and critical technologies considering that suppliers have specific knowledge and competencies.

In countries like the United Kingdom and United States, large enterprises that choose to downsize and concentrate on core competences, have increased their collaboration with these agents to guarantee a supply of quality inputs. The high degree of efficiency attained is one of the main reasons for cooperating with suppliers in terms of new products or processes (Tether 2002; Bayona et al. 2001; Santamaría \& Rialp 2007). Suppliers are the partners of choice when the enterprise's objectives have a commercial nature, such as entering new markets or internationalization (Bayona et al. 2001, Santamaría \& Rialp, 2007). These agents not only assist the development of products and processes, quality improvement and market adaptation, but also productivity and 
flexibility. Reduction of production costs is another reason to cooperate with suppliers, likewise costs and risks involved in new product development (Chung \& Kim, 2003).

\section{Competitors}

Establishing a relationship with competitors is normally referred as horizontal cooperation. Competitors are an external source that can be involved in the innovation process (Von Hippel, 2005). The knowledge generated by these agents can easily be accessed and exploited by firms that do not hold a high level of internal technological competence (Cohen \& Levinthal, 1990). This type of relationship is quite appealing, considering that it contributes to intensify international competitiveness in enterprises, industries and countries and to solve issues associated to market failures and technological deficiencies. Cooperation with competitors involves, on the one hand a reduction in investment risk and market uncertainty, and on the other sharing costs when enterprises initiate their R\&D activities (Harabi, 2002). According to Von Hippel (2005), enterprises improve products and processes by learning from their competitors, through know-how exchange.

Nevertheless, there are risks associated with the possibility of competitive behaviour and spillover of key knowledge to competitors (Miotti \& Sachwald, 2003). Therefore, cooperation is more likely to occur either in protected areas, or sharing knowledge that is not vital. Enterprises avoid areas that may raise competition and favour cooperation on solving common issues (Tether, 2002; Cassiman \& Veugelers, 2002) such as collaborating on basic research/projects or establishing standards in the sector (Tether, 2002).

\section{Consultants and experts}

Enterprises tend to seek alternative sources of knowledge and information when the development of innovations is affected, in particular when it is not evolving as fast as needed or does not correspond to enterprise's expectations. Thus, consultants and experts are a suitable solution (Tether, 2002). These agents are a source of specialized knowledge and skills that provide a wide range of valuable inputs for innovation development.

Consultants and experts render possible experience sharing, concerning the definition and articulation of specific innovation needs, offer ideas on new needs and solutions, or even allow idea transfer among enterprises (Bessant \& Rush, 1995). Besides, these agents can bring to the enterprise different points of view as they are not familiar with its products and processes, since the enterprise staff can sometimes be an obstacle to new ideas. The contributions brought by this type of agents have encouraged a growth in the number of effective innovative ideas (Bruce \& Morris, 1998).

\section{Universities and research institutes}

A common form of partnership is the cooperation with scientific agents, particularly in science-based firms (Castro \& Fernández, 2006). Universities and research institutes have an important role in the development of technological innovations, contributing to new scientific and technological knowledge (Drejer \& Jorgensen, 2005). This type of collaboration does not bring any type of commercial risk, unlike cooperation with 
competitors, as it is focused on generating R\&D knowledge of a basic or generic nature and not introducing it in the market (Miotti \& Sachwald, 2003). Cooperation with universities is a way of sharing costs as it exploits knowledge which is publically available.

Universities, as well as their research institutes, are constantly creating and developing scientific knowledge. As research in firms intensifies it becomes very expensive, then specialized academic knowledge is brought to balance and complement the firm's R\&D in order to gain access to rising technologies and achieve technological discovers that lead to distinctive commercial products (Spencer, 2003). Probably, one of the reasons why enterprises chose this source may be to benefit from public funds destined to research (Bayona et al., 2001; Cassiman \& Veugelers, 2002; Miotti \& Sachwald, 2003; Fontana et al., 2006). It is quite usual for policy-makers the encouragement of the relationship between enterprises and research institutes as a mandatory requisite to subsidize projects with public funds.

Although cooperation with these agents is very useful, enterprises must have an important in-house $R \& D$ capability in order to absorb the scientific knowledge generated (Cohen \& Levinthal, 1990). Although universities and their research institutes are acknowledged as key players in new product development, their role in the innovation process is not yet totally clarified (Reichstein \& Salter, 2006).

\section{Research framework}

The research proposition will be, firstly to identify the sectors of Portuguese economy more willing to engage in cooperation initiatives for innovating, and secondly to dig into the scale and scope dimensions of this cooperation, i.e., know which sources/agents they mostly use (scope) and with which relative intensity (scale). This kind of approach is relevant as it suggests patterns in terms of nature and intensity of use, thus assessing openness levels and related factors, for future OI strategy effectiveness. The dataset used in this work is provided by the Community Innovation Survey (CIS) 2012, which collects information on four major types: product/service, process, organizational, and marketing innovation. In this research, we focused on the first two main types: product/service and process innovations.

\subsection{CIS instrument and sampling}

For this study a secondary dataset was used from the CIS-2012 (DGEEC, 2014). The CIS, operation acronym in the Eurostat for Community Innovation Survey, is the main statistical survey (mandatory for EU member states) on innovation in companies. European Union employs this main statistical instrument to monitor Europe's progress in the area of innovation, which is conducted by national statistical offices. In Portugal, following the methodological recommendations of Eurostat, the CIS aims to directly collect information on innovation (product, process, marketing, and organizational) in companies. Data collection corresponds to the period of 2010-2012 and contemplates Portuguese companies with 10 or more employees, belonging to the sectors (NACE) presented in Table 1. The sample consisted of 9423 companies, based on census combination (for companies with 250 or more persons employed) and random sampling 
for other companies. In the corrected sample of 7995 companies were considered 6840 valid answers (i.e., response rate of $86 \%$ ).

Table 1. Sample distribution by sector in CIS 2012 instrument

\begin{tabular}{|l|l|l|}
\hline \multicolumn{1}{|c|}{$\begin{array}{c}\text { NACE } \\
\text { REV3 }\end{array}$} & \multicolumn{1}{|c|}{ Description } & $N^{\mathbf{o}}$ of firms \\
\hline $7-9$ & Mining and quarrying & 73 \\
\hline $10-12$ & Food, beverages, tobacco & 323 \\
\hline $13-18$ & Textiles, wearing, leather, wood, paper, printing & 889 \\
\hline $19-25$ & Coke, chemicals, non-metal, metal products & 1436 \\
\hline $26-27$ & Computer, electrical equip & 144 \\
\hline $28-33$ & Machinery, transport equip, furniture & 808 \\
\hline $35-39$ & Electricity, gas, water supply, sewearage, waste & 284 \\
\hline $42-43$ & Construction & 36 \\
\hline $46-53$ & Wholesale, retail trade, transportation, storage & 1642 \\
\hline $58-63$ & Information, communication & 376 \\
\hline $64-75$ & Financial, insurance, legal, accounting, others & 735 \\
\hline 86 & Health & 94 \\
\hline & Total & 6840 \\
\hline
\end{tabular}

Source: own elaboration based on CIS 2012 data

The CIS instrument provides useful information on how firms interrelated with its surrounding external environment in order to access information considered important for the development of new innovation projects or the completion of existing ones. Firms may use external agents as information sources or engage in more formal cooperation activities, meaning their active participation with other enterprises or institutions on innovation accomplishments.

\subsection{Nature of the innovation process}

Firms were asked about the way product and process innovations have been developed. To the question: "Who developed the innovation", four possible answers were available: (1) The firm; (2) The firm in cooperation with other firms or institutions; (3) The firm adopting or modifying goods or services originally developed by other firms or institutions; (4) Other firms or institutions.

In order to assess the openness level, we started to distinguish between 'cooperationbased' and 'firm-based' innovators. Table 2 gives the frequencies for these variants (with a $0=$ "No"; $1=$ "Yes" coding). The percentages indicate the proportion of firms with positive answers and the innovation rate is given by the ratio between the number of innovative firms and the total number of sample firms.

Table 2. Cooperation-based vs firm-based innovation

\begin{tabular}{|l|r|r|r|}
\hline & \multicolumn{1}{|c|}{$\begin{array}{c}\text { Innovation } \\
\text { rate }\end{array}$} & $\begin{array}{c}\text { Coop-based } \\
\text { innovation }\end{array}$ & $\begin{array}{c}\text { Firm-based } \\
\text { innovation }\end{array}$ \\
\hline Product Innovation & $33 \%$ & $16 \%$ & $28 \%$ \\
\hline Process Innovation & $40 \%$ & $19 \%$ & $29 \%$ \\
\hline
\end{tabular}

Source: Own elaboration based on CIS 2012 data 
These figures show that process innovation is more developed than product innovation. This incidence could be related to the present economic crisis (whose worst influences began in 2008). With lower investments, product innovations are most likely postponed. However, investigation of other CIS periods will be necessary for more accurate longitudinal discussions. Firm-based innovation is higher than cooperation-based initiatives for both types of innovation. This difference is higher in product innovation, what suggests that firms tend to be more cautious to cooperate when there is exposure of new products potentially profitable. Findings reveal that many Portuguese firms are still closed to internal resources and might miss several opportunities (Chesbrough 2003; Laursen \& Salter 2006).

Bigger firms, with head offices abroad, use both internal and external environments more often (Rigby \& Zook 2002; Navarro 2002) achieving successful innovations (Cohen \& Levinthal 1990). Outsiders can provide diverse solutions to complex problems and foster combined innovation to generate new applications, influencing the firm's ability to innovate positively. The trend is towards OI due to crises, globalization, internet potential and innovation sustainability.

\section{Main results}

Revisiting the research proposition, the first objective is to identify the sectors that most engage in cooperation initiatives for innovating.

\subsection{Sectorial results}

Table 3 shows the percentages obtained for cooperation and firm-based innovation by sector and type of innovation.

Table 3. Cooperation-based vs. firm-based innovation by sector

\begin{tabular}{|l|l|c|c|c|c|c|c|}
\hline $\begin{array}{l}\text { NACE } \\
\text { code }\end{array}$ & \multicolumn{1}{|c|}{ Sector } & $\begin{array}{c}\text { Product } \\
\text { Innov }\end{array}$ & $\begin{array}{c}\text { Process } \\
\text { Innov }\end{array}$ & $\begin{array}{c}\text { Prod. } \\
\text { Innov - } \\
\text { Coop } \\
\text { based }\end{array}$ & $\begin{array}{c}\text { Proc. } \\
\text { Innov - } \\
\text { Coop } \\
\text { based }\end{array}$ & $\begin{array}{c}\text { Prod. } \\
\text { Innov - } \\
\text { Firm } \\
\text { based }\end{array}$ & $\begin{array}{c}\text { Proc. } \\
\text { Innov - } \\
\text { Firm } \\
\text { based }\end{array}$ \\
\hline 26 & $\begin{array}{l}\text { Computer manufacturing, } \\
\text { electronic and optical products }\end{array}$ & $73,6 \%$ & $67,9 \%$ & $45,3 \%$ & $41,5 \%$ & $62,3 \%$ & $50,9 \%$ \\
\hline 42 & Civil engineering & $24,0 \%$ & $56,0 \%$ & $12,0 \%$ & $40,0 \%$ & $16,0 \%$ & $32,0 \%$ \\
\hline 47 & $\begin{array}{l}\text { Retail trade, except motor vehicles } \\
\text { and motorcycles }\end{array}$ & $46,7 \%$ & $73,3 \%$ & $46,7 \%$ & $46,7 \%$ & $40,0 \%$ & $60,0 \%$ \\
\hline 65 & $\begin{array}{l}\text { Insurance, reinsurance and pension } \\
\text { funding, except compulsory social } \\
\text { security }\end{array}$ & $72,7 \%$ & $67,3 \%$ & $50,9 \%$ & $47,3 \%$ & $58,2 \%$ & $49,1 \%$ \\
\hline 72 & $\begin{array}{l}\text { Scientific research and } \\
\text { development (R\&D) }\end{array}$ & $63,3 \%$ & $56,7 \%$ & $40,0 \%$ & $30,0 \%$ & $56,7 \%$ & $46,7 \%$ \\
\hline 86 & Human health activities & $53,2 \%$ & $54,3 \%$ & $33,0 \%$ & $40,4 \%$ & $51,1 \%$ & $38,3 \%$ \\
\hline
\end{tabular}

The sectors that most innovate are computer manufacturing, electronic and optical products followed by insurance, reinsurance and pension funding, and then scientific research and development $(\mathrm{R} \& \mathrm{D})$. However, firm-based innovation is higher than 
cooperation-based innovation for the majority of sectors, especially in product innovation. This suggests that firms tend to be more open to collaborate with others when there is no new product involved.

In order to have a visual diagnosis, figures 1 and 2 illustrate the nature of the innovation process by sector. Besides identifying the sectors more willing to engage in cooperation to innovate, these charts allow to compare the nature of the innovation process (firmbased or cooperation-based) by sector and type of innovation (product/process). Regarding product innovation, figure 1 shows an inferior incidence of cooperationbased innovation when compared to firm-based innovation regardless the sector. Firms tend to be reluctant to cooperate when they have new products/services (Tether, 2002; Cassiman and Veugelers, 2002). This may be related with path dependency factors of the Portuguese economy whose firms miss early collective entrepreneurial culture, have difficulties obtaining finance and are risk averse (Sarkar, 2014).

Figure 1. Product innovation: cooperation vs. firm-based innovation by sector

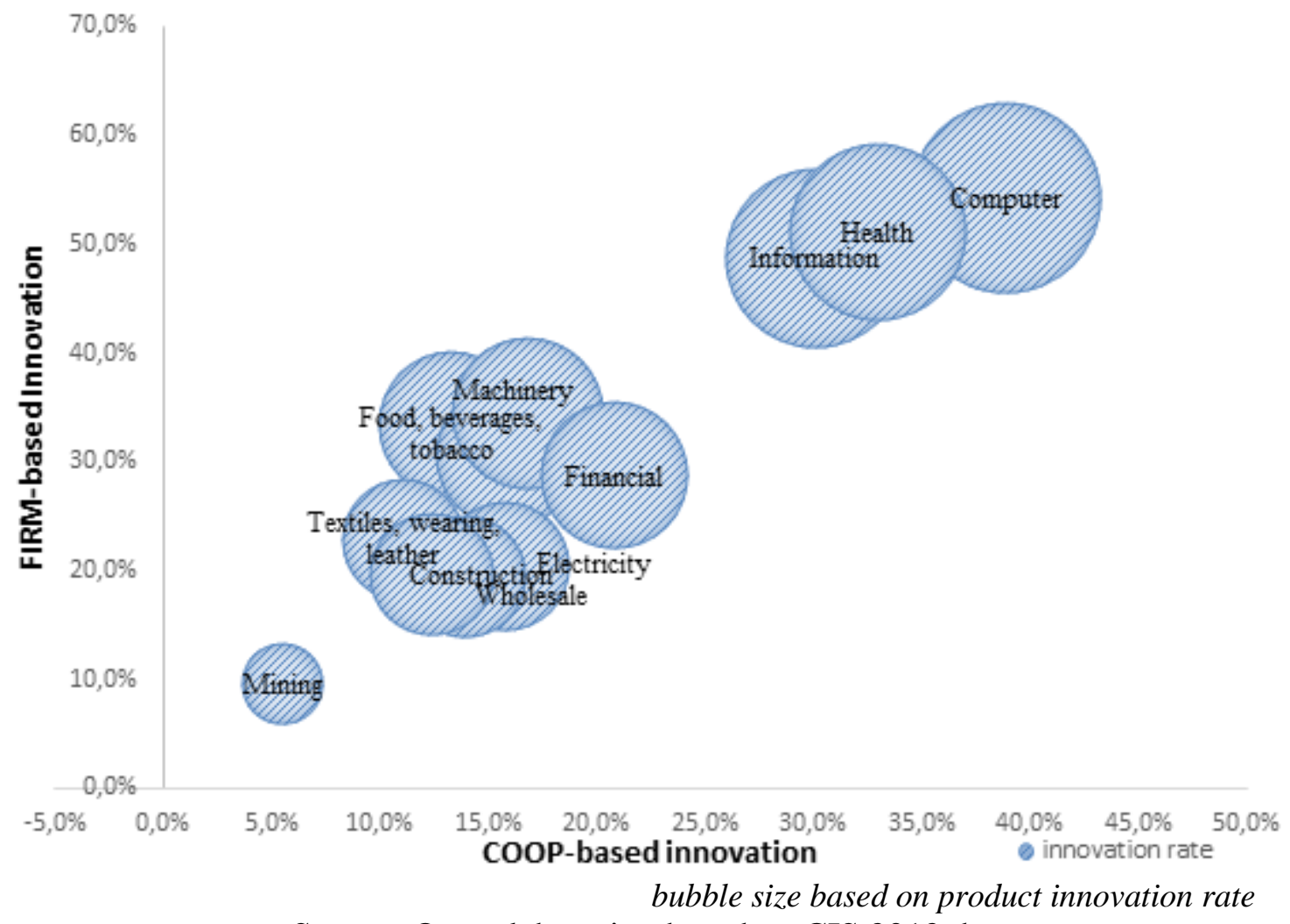

Source: Own elaboration based on CIS 2012 data

A slightly different sectoral behavior is observed when considering process innovation (Figure 2). Here the health sector has a higher incidence of cooperation-based innovation. This pattern applies, in minor degree, to construction industry.

Figure 2. Process innovation: cooperation vs. firm-based innovation by sector 


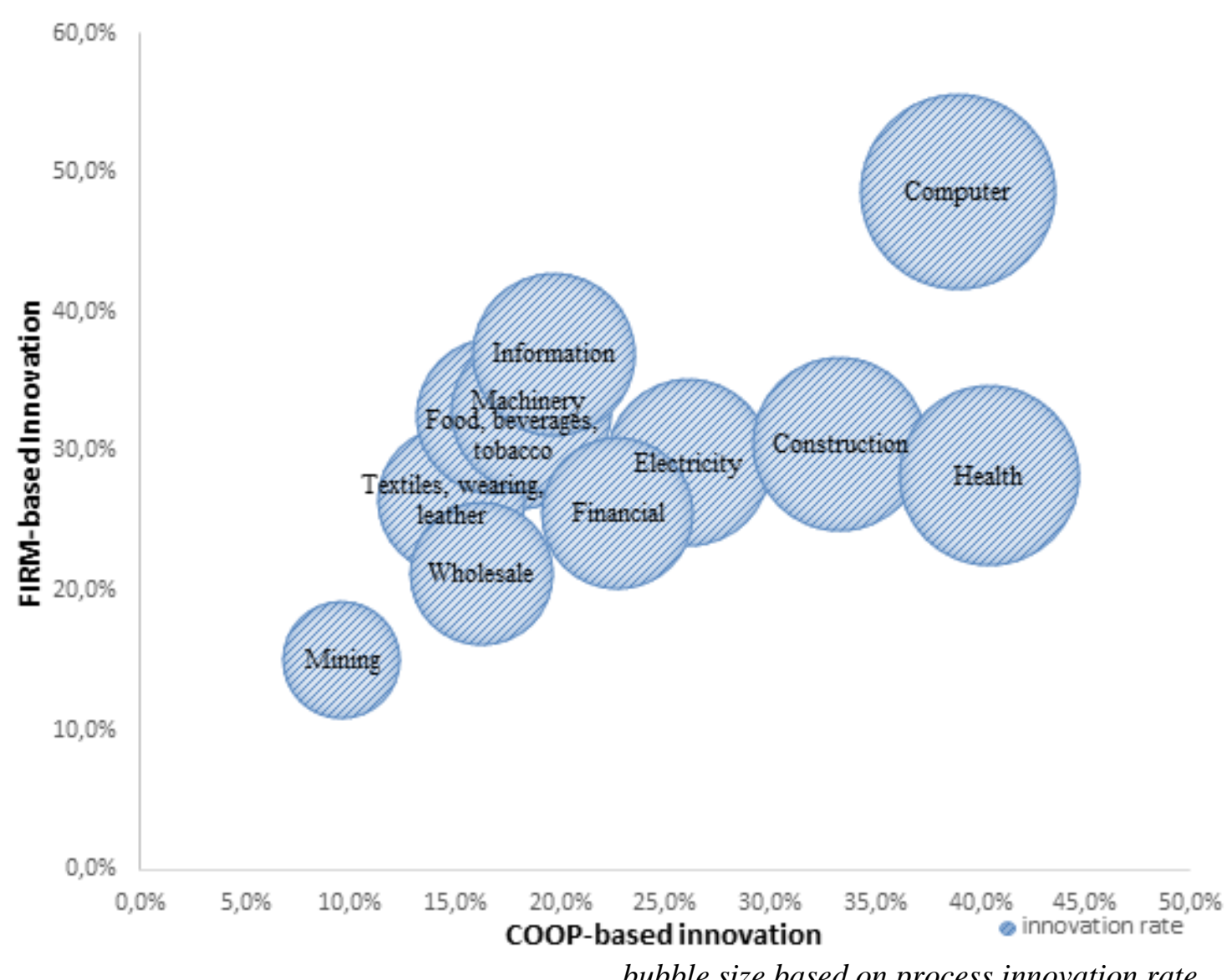

Source: Own elaboration based on CIS 2012 data

Continuing the research proposition, a second objective is to dig into the scale and scope dimensions of the cooperation acknowledged, i.e., know which sources/agents those firms mostly use (scope) and with which relative intensity (scale).

\subsection{Scale and scope of cooperation}

According to the design of CIS, firms may cooperate with different partners such as: other firms in the group; suppliers; customers; competitors; consultants; universities and $\mathrm{R} \& \mathrm{D}$ laboratories. The geographical reach of cooperation may vary, as cooperation can be developed with: Portuguese partners; European partners; USA; China/India or others. However the following figures show that there is a focus on national partners.

The following charts allow comparing the cooperation sources/agents used by sector (scope) and relative intensity of use (scale). In the computer sector (Figure 3), whose incidence is in firm-based product innovation, the external sources/agents most used are universities and R\&D labs, followed by suppliers and private customers. This could be related to the previously referred reluctance of exposing new ideas/products to concurrence.

Figure 3. Scale and scope of cooperation in Computer sector 


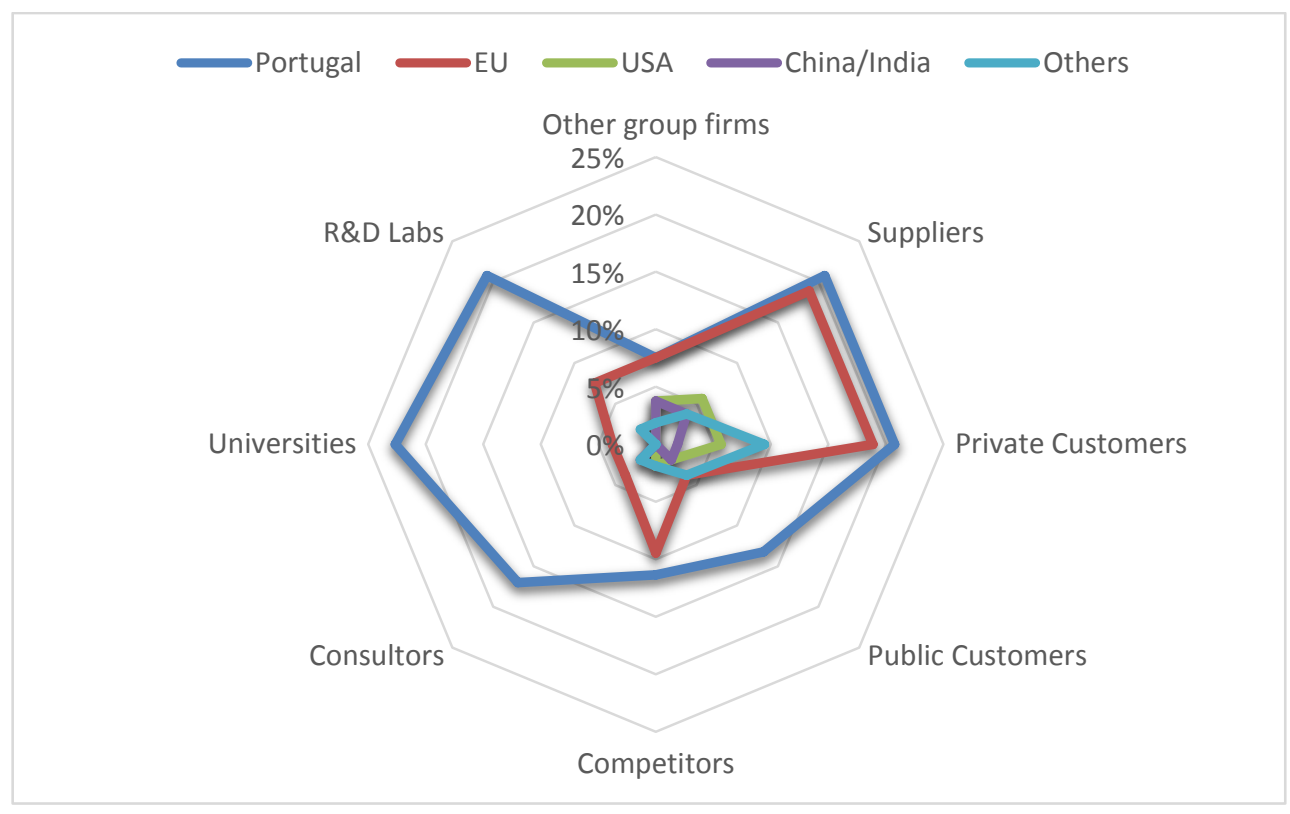

In the civil engineering sector (Figure 4), whose incidence is in cooperation-based process innovation, the external sources/agents most used are universities and competitors, followed by other group firms. Indeed, construction enterprises count on their firms' group for expanding and sharing costs. Competitors can be a useful source or cooperating agent for creativity, knowledge transfer and internationalization. These goals can be attained through developing innovation as an integrated process (Barata \& Fontainha, 2017).

Figure 4. Scale and scope of cooperation in Civil engineering sector

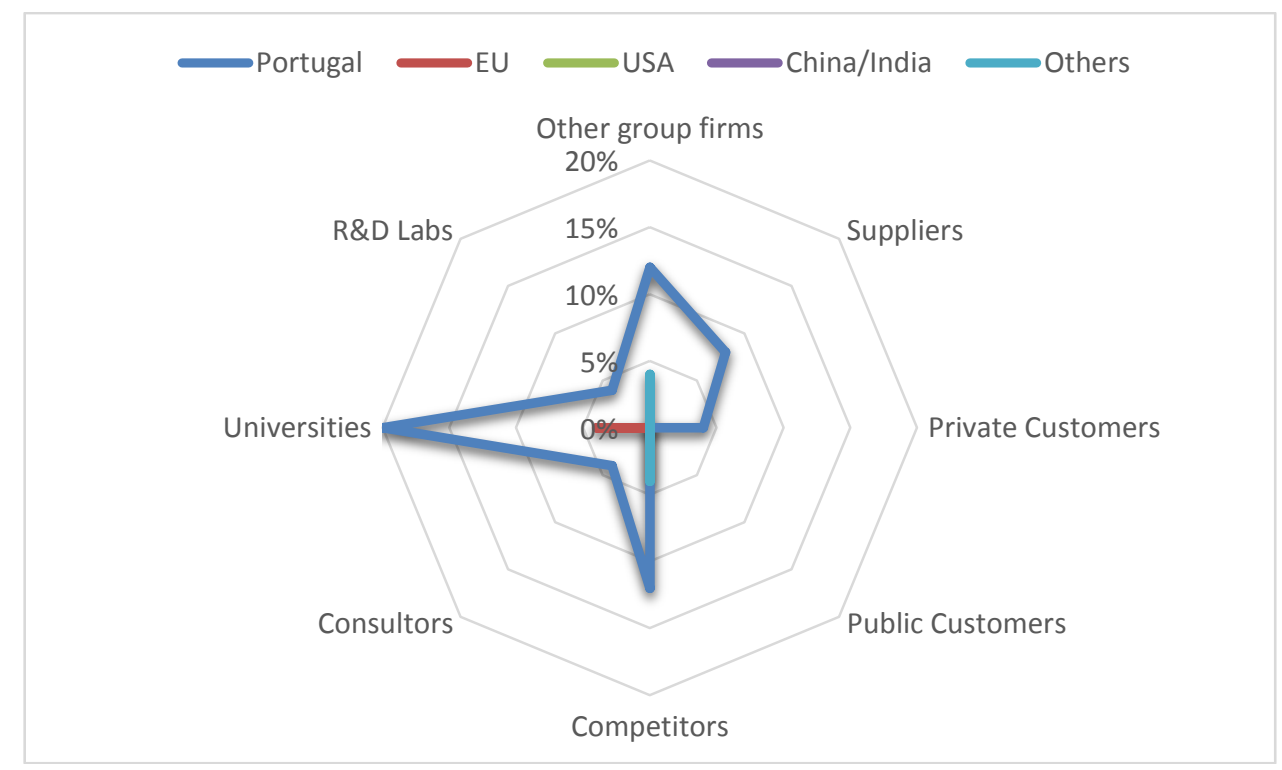

In the retail trade sector (Figure 5), whose incidence is in firm-based process innovation, the external sources/agents most used are other group firms, suppliers and private customers. Many times, retail trade enterprises innovate in services and supporting processes (orders, delivery, cross-selling, after-sales, online shopping, etc.). And increasingly they develop innovations based on private customers' suggestions and 
contributions (even through social networks). Suppliers are also an important source/ agent of information and market penetration.

Figure 5. Scale and scope of cooperation in Retail trade sector

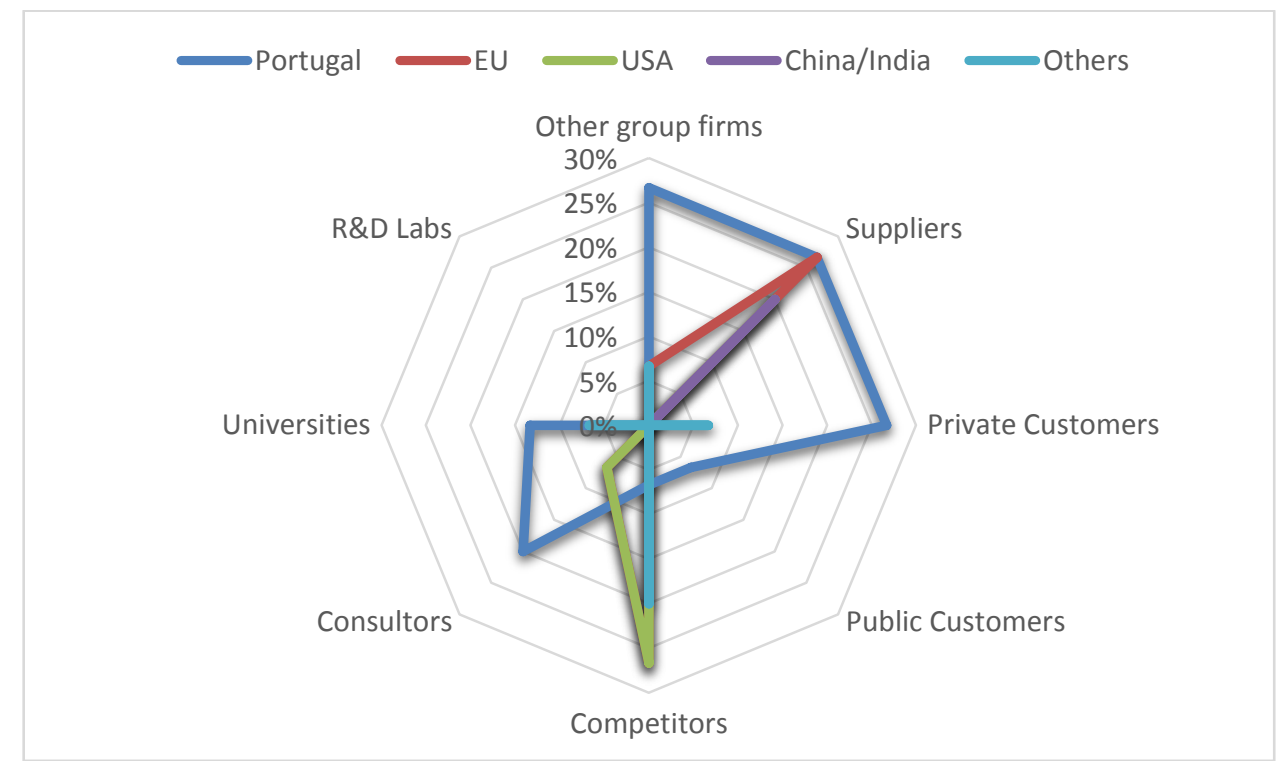

In the insurance sector (Figure 6), whose incidence is in firm-based product innovation, the external sources/agents most used are suppliers, followed by private customers and competitors. Like consultancy, these firms can provide a stream of innovations to clients which need external expert knowledge to face trends of business dynamics (McKenna 2006). In this kind of sectors strong interactions between providers and customers arise, where each transaction is tailored to their needs. As knowledgeintensive services, they provide innovations to several agents who need expert knowledge to face business challenges. Thus, partnerships and other integrated initiatives and information are fundamental (Cesário et al., 2015).

Figure 6. Scale and scope of cooperation in Insurance sector

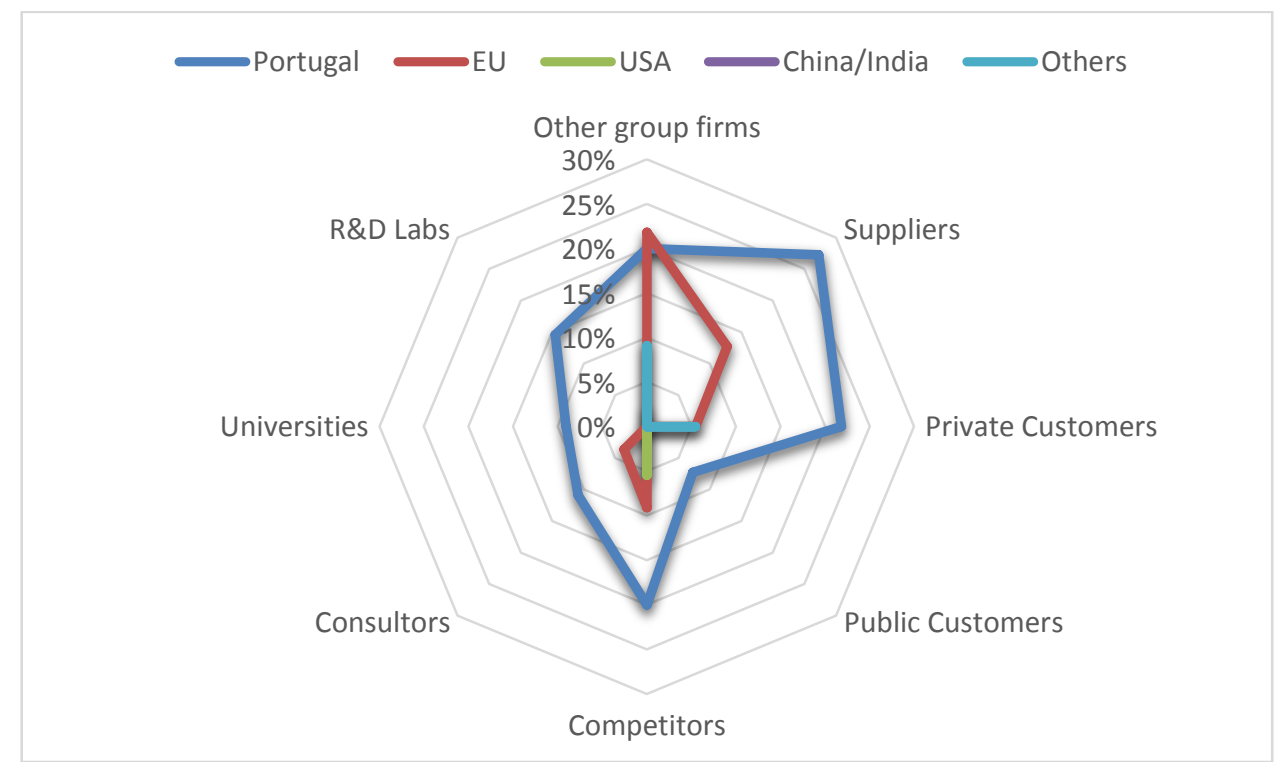


In the $R \& D$ sector (Figure 7), whose incidence is in firm-based product innovation, the external sources/agents most used are universities and private customers, followed by $\mathrm{R} \& \mathrm{D}$ labs.

Figure 7. Scale and scope of cooperation in R\&D sector

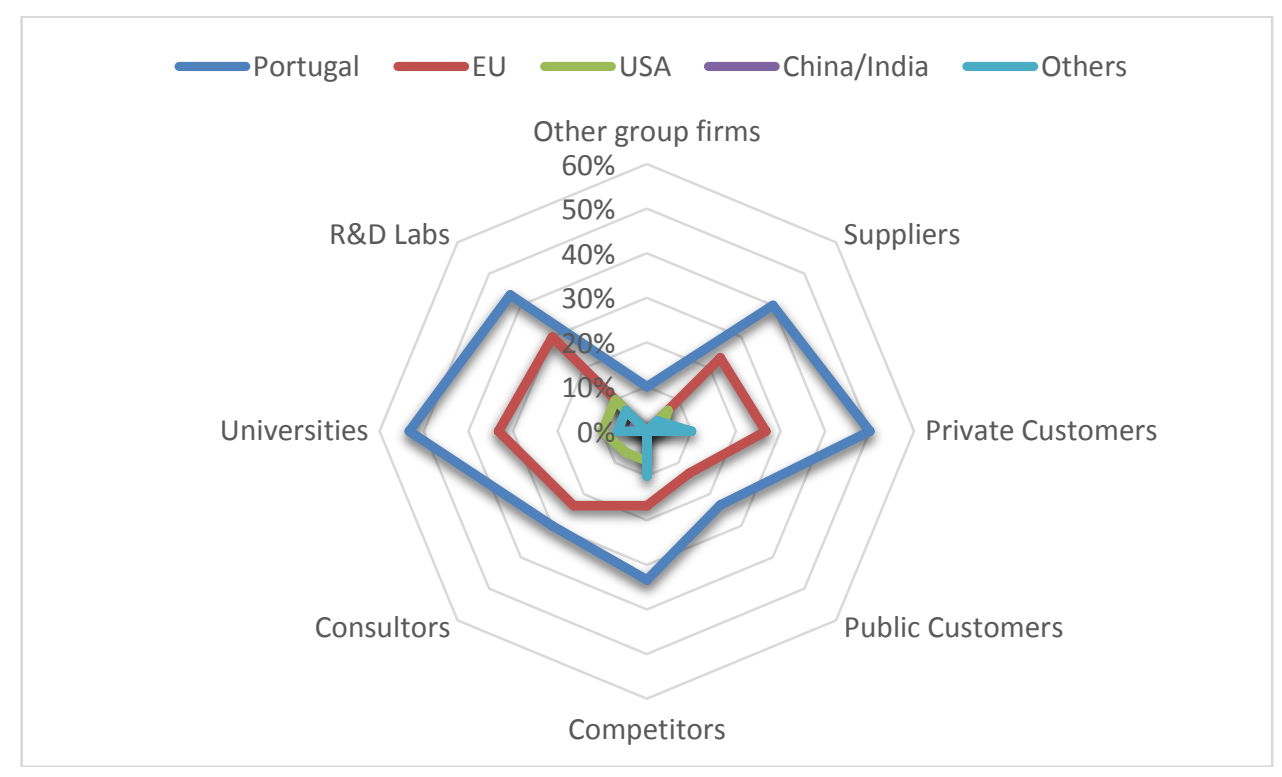

Finally, in the health sector (Figure 8), whose incidence is in firm-based product innovation, the external sources/agents most used are universities, followed by suppliers and $R \& D$ labs. This sector however is increasing its cooperation when dealing with process innovations. In Portugal, health companies are 'awaking' for the potential of business intelligence through process-based information systems (ERP and $\mathrm{SCM}^{1}$ ).

Figure 8. Scale and scope of cooperation in Health sector

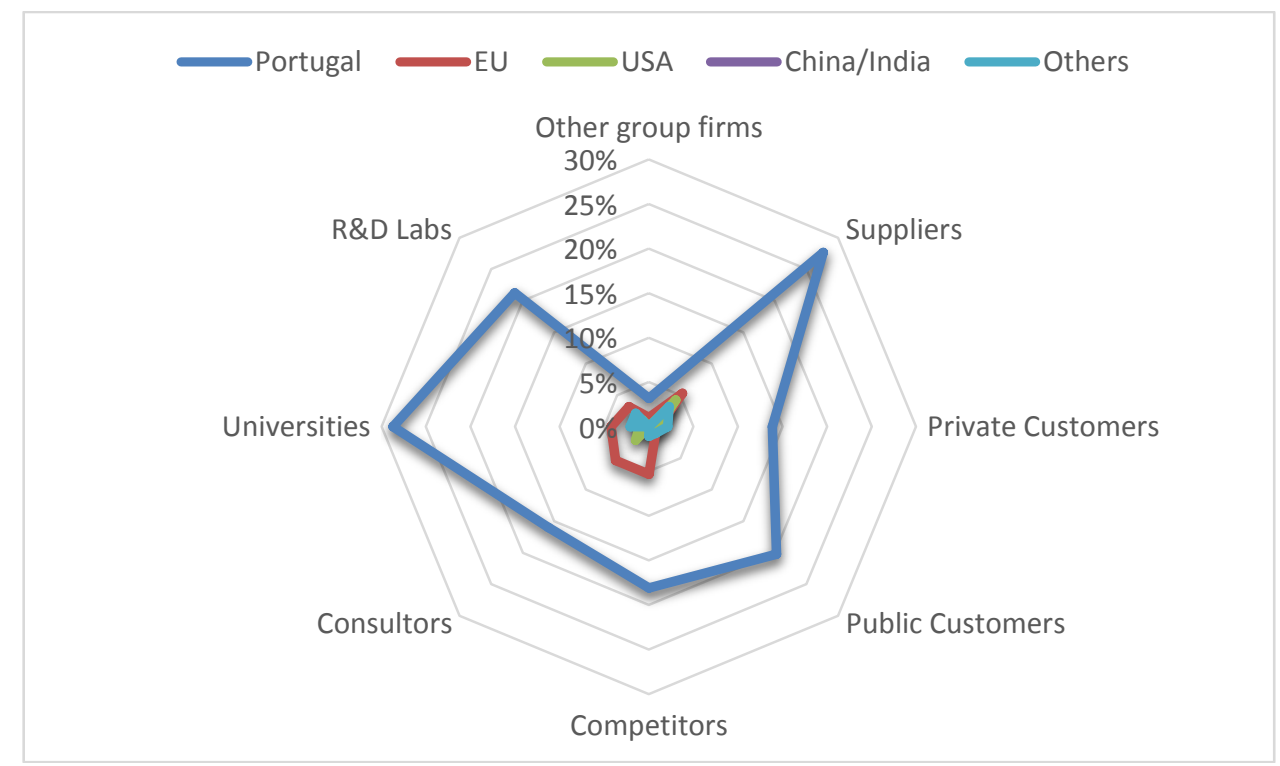

\footnotetext{
${ }^{1}$ ERP - Enterprise Resource Planning systems; SCM - Supply Chain Management systems.
} 
From these figures, we can acknowledge that main innovating sectors in the Portuguese economy are research-based (computer, civil engineering, R\&D) or knowledge-based (insurance, health) or service-based (retail trade). The external sources/agents most commonly used by the first are universities, suppliers by the second and firms' group by the third. Private customers are important sources for all types of sectors. These results are in line with the fact that Portuguese economy is mainly based on small and mediumsized firms (SME) which increasingly focus on services and knowledge. Customers' data allow to expand the knowledge-base within their applied research and to materialize knowledge into goods and services (Sánchez-González \& Herrera, 2014). Next section discusses why this is important for Portuguese firms and economy in general.

\section{Discussion and study limitations}

From both sectorial and scope/scale assessments, this work suggests that the main OI drivers in the case of Portugal are: 1) customers, universities and suppliers as agents/ sources; and 2) health and construction as economic activities. It is interesting that the most innovative sectors (computers and optical, insurance and R\&D) are not necessarily the most OI oriented ones (health, construction). Matching these findings with the literature review, we acknowledge that Portugal is one of the high portion of European countries whose OI oriented firms resort to the inbound mode (outside->in).

Contextualizing entrepreneurial culture in Portugal, the Global Entrepreneurship Monitor (GEM) suggests that about 8 in 100 people are entrepreneurs in Portugal. Reasons include the low incomes characterizing this country, missing early collective entrepreneurial culture, difficulties obtaining finance and risk aversion (Sarkar, 2014). These issues reflect on the low 'maturity level' of innovation return management in Portugal. The work of Kastelle (2012) on a matrix for innovation management helps to discuss some reasons behind this. Its main underlying issue is the considerable R\&D spent without the correspondent return. The main factors pointed out, sustained by case studies, are related with a classic strategy of innovation commitment increase without the correspondent increase in innovation competence. For example, the P\&G case (Procter \& Gamble) initiated the 'connect \& develop' program designed to use OI to improve their innovation outcomes. They significantly reduced R\&D spent cutting back on activities that were not leading to the outcomes needed. With the right partners, the next step was to get more ideas out into the world moving into the 'fit for purpose' phase. $P \& G$ got better at executing ideas and was learning about how to use its resources more effectively. Then, it improved its idea selection process and its innovation competence took a jump forward. Rogo et al. (2014) corroborate these aspects through their work on value drivers of intellectual capital at assessing the performance of OI practices.

Thus, entrepreneurs and innovation agencies need to know this stage and factors behind it in order to help Portuguese firms achieve a relevant level of competence attributes (percentage of ideas successfully executed and diffused; effective idea management process; portfolio of types of innovation; both small and large scale innovation; culture of systematic experimentation; learning from failure; etc.). This study cannot be generalized to other countries as it is limited to Portuguese economy and misses other statistics like longitudinal data (through other CIS in time). Also misses a deepen analysis about the duration and specific goals of the OI practices acknowledged. 


\section{Conclusion and future research}

The present research aims to identify the sectors of Portuguese economy more involved in cooperation to accomplish innovation. After appraising the nature of the innovation process in terms of cooperation or firm-based innovation, a more detailed analysis on the scale and scope of cooperation is developed, i.e., an assessment of the sources and/ or agents Portuguese firms most use (scope) and with which relative intensity (scale). Findings reveal that main innovating sectors in the Portuguese economy are researchbased, knowledge-based and service-based. The external sources/agents most commonly used by the first are universities, suppliers by the second and firms' group by the third. Private customers are important sources for all types of sectors, what means that Portuguese firms generally use customers' information and relations for innovation purposes. These results are in line with the fact that Portuguese firms are mainly small and medium-sized and increasingly focus on services and knowledge.

In present economies firms need to balance internal sources and competences with ideas from outside and interact with a large number of players (Lundvall, 2010; Laursen \& Salter, 2006). This is the main strength of the OI model in which external knowledge connections are a vital factor and a complement to internal research (Chesbrough et al., 2006). However, Portuguese firms are less mature in OI comparing to other European countries. For instance, an attribute of the 'sixth generation' model of innovation (Kotsemir \& Meissner, 2013) is the strategic integration with competitors ${ }^{2}$. Though this cooperation agent is used by few sectors in Portugal, construction and insurance use it to increase openness for innovating and internationalizing processes (Barata \& Fontainha, 2017).

The firms' capacity to explore the knowledge provided by external agents depends on the openness toward new opportunities, which in turn depends on the firm's knowledge stock and on the qualification of its employees (Pinto et al., 2015). An interesting initiative that has been stimulating the propensity of Portuguese firms for OI are the innovation accelerator programs (for start-ups' launching and support). Facing the increasingly dynamic economy, diverse partners can provide solutions to complex problems, foster combinatorial innovation and share risks and costs of radical innovations. OI is crucial due to crises, globalization, internet potential and innovation sustainability. This model of innovation can create conditions for unique and multifunctional products and services.

From 2008 a global crisis influences the Portuguese economy, affecting many firms. Future research should explore this topic using other CIS datasets to verify which changes occurred concerning innovation agents/sources and scale/scope. Also to explore how effective have been the OI trends in the sectors referred to know which sources and OI practices are more likely to improve their innovation performance.

\footnotetext{
${ }^{2}$ Other attributes of the sixth generation of innovation are: better internal communication, tacit/informal knowledge, digital connectivity among the group firms, and intensive use of knowledge.
} 


\section{Acknowledgements}

This paper was supported by national funds provided by FCT- Foundation for Science and Technology through project UID/SOC/04020/2013.

\section{References}

Abramovsky, L., Kremp, E., López, A., Schmidt, T. \& Simpson, H., 2005. Understanding co-operative R\&D activity: Evidence from four European countries. Economics of Innovation and New Technology, 18(3), 243-265.

Amara, N. \& Landry, R., 2005. Sources of information as determinants of novelty of innovation in manufacturing firms: Evidence from the 1999 statistics Canada innovation survey. Technovation, 25, 245-259.

Barata, J. M. \& Fontainha, E., 2017. Determinants of innovation in European construction firms. Technological and Economic Development of Economy, 23(6), 915936.

Bayona, C., García-Marco, T. \& Huerta, E., 2001. Firms' motivations for cooperative R\&D: An empirical analysis of Spanish firms. Research Policy, 30(8), 1289-1307.

Becker, W. \& Dietz, J., 2004. R\&D cooperation and innovation activities of firms evidence for the German manufacturing industry. Research Policy, 33(2), 209-223.

Belo, A., Fernandes, S. \& Castela, G., 2016. Social network enterprise behaviors and patterns in SMEs: Lessons from a Portuguese local community centered around the tourism industry, Technology in Society, 44, 15-22. doi:10.1016/j.techsoc.2015.11.004

Bessant, J. \& Rush, H., 1995. Building bridges for innovation: The role of consultants in technology transfer. Research Policy, 24, 97-114.

Bidault, F., Despres, C. \& Butler, C., 1998. The drivers of cooperation between buyers and suppliers for product innovation. Research Policy, 26, 719-732.

Brettel, M. \& Cleven, N., 2011. Innovation Culture, Collaboration with External Partners and NPD Performance. Blackwell Publishing Ltd, 20(4), 253-272.

Bruce, M. \& Morris, B., 1998. In-house, outsourced or a mixed approach to design, In: Bruce, M. \& Jevnaker, B. (Eds.) Management of design alliances: Sustaining competitive advantage, Wiley, Chichester.

Cassiman, B. \& Veugelers, R., 2002. R\&D cooperation and spillovers: Some empirical evidence from Belgium. American Economic Review, 92(4), 1169-1184. 
Castro, E. \& Fernández, I., 2006. La I+D empresarial y sus relaciones con la investigación pública española, In: J. Sebastián and E. Muñoz (Eds.) Radiografía de la investigación pública en España, Biblioteca Nueva, Madrid.

Cesário, M., Fernandes, S., Jesus, B. \& Barata, J.M., 2015. Sources of innovation: The case of Portuguese consultancy sector, Journal of Technology Management and Innovation, 10(3), 44-52.

Chesbrough, H., 2003. The era of open innovation. Sloan Management Review, Summer, 35-41.

Chesbrough, H., Vanhaverbeke, W. \& West, J., 2006. Open innovation: Researching a new paradigm, London: Oxford University Press.

Chung, S. \& Kim G., 2003. Performance effects of partnership between manufacturers and suppliers for new product development: The supplier's standpoint. Research Policy, $32,587-603$.

Cohen, W. \& Levinthal D., 1990. Absorptive capacity: A new perspective on learning and innovation. Administrative Science Quarterly, 35, 128-152.

Cornish, S., 1997. Product innovation and the spatial dynamics of market intelligence: Does proximity to markets matter?. Economic Geography, 73, 143-165.

Cricelli, L., Greco, M. \& Grimaldi, M., 2016. Assessing the open innovation trends by means of the Eurostat Community Innovation Survey. International Journal of Innovation Management, 20(3), 1-30.

DGEEC, 2014. CIS 2012 - Community Innovation Survey. General Direction of Statistics in Education and Science, http://www.dgeec.mec.pt/np4/207/ (accessed in June 2015).

Drejer, I. \& Jørgensen, B.H., 2005. The dynamic creation of knowledge: Analysing public-private collaborations. Technovation, 25, 83-94.

Enkel E., Gassmann O. \& Chesbrough H., 2009. Open R\&D and open innovation: Exploring the phenomenon. R\&D Management, 39(4), 311-316.

Ettlie, J.E. \& Reza, E., 1992. Organizational integration and process innovation. Academy of Management Journal, 34(4), 795-827.

European Innovation Scoreboard- EIS, 2017. European Innovation Scoreboard Interactive Tool, http://ec.europa.eu/growth/industry/innovation/factsfigures/scoreboards_pt (accessed in August 2017).

Fontana R., Geuna, A. \& Matt, M., 2006. Factors affecting university-industry R\&D projects: The importance of searching, screening and signaling. Research Policy, 35, 309-323. 
Freel, M. \& Harrison, R., 2006. Innovation and cooperation in the small firm sector: Evidence from Northern Britain. Regional Studies, 40(4), 289-305.

Greco, M., Grimaldi, M. \& Cricelli, L., 2016. An analysis of the open innovation effect on firm performance. European Management Journal, 34(5), 501-516.

Håkansson, H. \& Eriksson, A. K., 1993. Getting innovations out of supplier networks. Journal of Business-to-Business Marketing, 1, 3-16.

Hanna, V. \& Walsh, K., 2008. Interfirm cooperation among small manufacturing firms. International Small Business Journal, 26(3), 299-321.

Harabi, N., 2002. The impact of vertical R\&D cooperation on firm innovation: An empirical investigation. Economics of Innovation and New Technology, 11(2), 93-108.

Hayat, U., 2014. Social network analysis (SNA) and start-ups: An interview with Murat Ünal, https://blogs.cfainstitute.org/investor/2014/12/03/social-network-analysis-snaand-start-ups-an-interview-with-murat-unal/ (accessed in August 2017).

Jeppesen, L.B., 2002. Making consumer knowledge available and useful. The case of the computer games, DRUID Working Paper No. 01-10, 2nd version.

Kastelle, T., 2012. Procter \& Gamble - Using open innovation to become a world class innovator, http://timkastelle.org/blog/2012/05/procter-gamble-using-open-innovationto-become-a-world-class-innovator/ (accessed in February 2016).

Kotsemir, M. \& Meissner, D., 2013. Conceptualizing the innovation process - trends and outlook, MPRA Paper No. 46504, National Research University - Higher School of Economics, Munich Personal Repec Archive.

Kuznets, S., 1962. Inventive activity: Problem of definition and measurement, In: National Bureau of Economic Research (Eds.) The rate and direction of inventive activity: Economic and social factors, Princeton: Princeton University Press.

Lundvall, B.A., 1988. Innovation as an interactive process: From user-producer interaction to the national system of innovation, In: Dosi, G., Freeman, R., Nelson, G., Silverberg, G. \& Soete, L. (Eds.) Technical Change and Economic Theory, London: Pinter.

Lundvall, B.A., 2010. National systems of innovation: Towards a theory of innovation and interactive learning, London: Anthem Press.

Michelino, F., Caputo, M., Cammarano, A. \& Lamberti, E., 2014. Inbound and outbound open innovation: Organization and performances. Journal of Technology Management and Innovation, 9(3), 65-82.

Miotti, L. \& Sachwald, F., 2003. Co-operative R\&D, why and with whom? An integrated framework of analysis. Research Policy, 32, 1481-1499. 
Navarro, A., 2002. La cooperación para la innovación en la empresa española desde una perspectiva internacional comparada. Revista Economía Industrial, 346, 47-66.

Pavitt, K., Robson, M. \& Townsend, J., 1987. The size distribution of innovating firms in the UK: 1945-83. Journal of Industrial Economics, 35, 297-316.

Peteraf, M., 1993. The cornerstones of competitive advantage: A resource-based view. Strategic Management Journal, 14(3), 179-191.

Piller, F. \& West, J., 2014. Firms, users, and innovation: An interactive model of coupled open innovation, In: Chesbrough, H., Vanhaverbeke, W. \& West, J. (Eds.) New frontiers in open innovation, Oxford University Press.

Pinto, H., Fernandez-Esquinas, M. \& Uyarra, E., 2015. Universities and knowledge intensive business services (KIBS) as sources of knowledge for innovative firms in Peripheral regions, Regional Studies, 49(11), 1873-1891.

Pittaway, L., Robertson, M., Munir, K., Denyer, D. \& Neely, A., 2004. Networking and innovation: A systematic review of the evidence. International Journal of Management Reviews, 5-6(3-4), 137-168.

Powell, W.W., Koput, K.W. \& Smith-Doerr, L., 1996. Interorganisational collaboration and the local of innovation: Networks of learning in biotechnology. Administrative Science Quarterly, 41, 116-145.

Propris, L., 2002. Types of innovation and inter-firm cooperation. Entrepreneurship \& Regional Development, 14(4), 337-353.

Reichstein, T. \& Salter, A., 2006. Investigating the sources of process innovation among UK manufacturing firms. Industrial Corporate Change, 15, 653-682.

Rigby, D. \& Zook, C., 2002. Open-market innovation. Harvard Business Review, 80(10), 80-89.

Rogo, F., Cricelli, L. \& Grimaldi, M., 2014. Assessing the performance of open innovation practices: A case study of a community of innovation. Technology in Society, 38, 60-80.

Sampson, R., 2007. R\&D Alliances and firm performance: The impact of technological diversity and alliance organization on innovation. Academy of Management Journal, 50(2), 364-386.

Sánchez-González, G. \& Herrera, L., 2014. Effects of customer cooperation on knowledge generation activities and innovation results of firms. Business Research Quarterly, 17(4), 292-302.

Santamaría, L. \& Rialp, J., 2007. Determinantes de la elección del socio tecnológico: Especificidades sectoriales y de tamaño. Cuadernos Económicos del ICE, 73, 37-64.

Sarkar, S., 2014. Entrepreneurship and innovation, Portugal: Escolar Editora. 
Tether, B.S., 2002. Who co-operate for innovation, and why. An empirical analysis. Research Policy, 31, 947-967.

Veugelers, R., 1997. Internal R\&D expenditures and external technology sourcing. Research Policy, 26(3), 303-315.

Veugelers, R. \& Cassiman, B., 1999. Make and buy in innovation strategies: Evidence from Belgian manufacturing firms. Research Policy, 28, 63-80.

Von Hippel, E., 2005. Democratizing innovation, Cambridge, MA: Ed. MIT Press. 